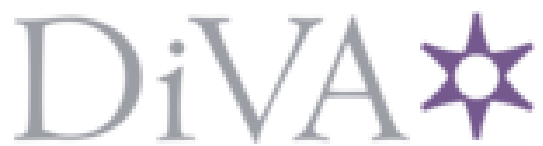

http://www.diva-portal.org

This is the published version of a paper published in Barn.

Citation for the original published paper (version of record):

Heikkilä, M., Furu, A-C., Hellman, A., Lillvist, A., Rantala, A. (2020)

Barns deltagande i förskole- och daghemskontext under inledningen av coronavirusets utbrott i Finland och Sverige

Barn, 38(2): 13-28

https://doi.org/10.5324/barn.v38i2.3703

Access to the published version may require subscription.

N.B. When citing this work, cite the original published paper.

Permanent link to this version:

http://urn.kb.se/resolve?urn=urn:nbn:se:umu:diva-173982 


\title{
Barns deltagande i förskole- och daghemskontext under inledningen av coronavirusets utbrott i Finland och Sverige
}

\author{
Mia Heikkilä, Ann-Christin Furu, Anette Hellman, Anne Lillvist och Anna \\ Rantala
}

\begin{abstract}
Sammanfattning
Coronapandemin är en ny samhällskris som är sparsamt beforskad varför olika perspektiv på coronaviruset behövs. Denna artikel bidrar till att fördjupa kunskapen om barns uttryck om coronaviruset bland annat genom att analysera personalens beskrivningar av barns uttryck kring coronavirusets utbrott i Finland och Sverige i daghems- och förskolekontext_i mars 2020. Det empiriska materialet består av 79 enkätsvar från personal i förskola och daghem. Begreppen deltagande och resiliens har använts som teoretisk bakgrund och dessa diskuteras i artikeln. Barnen visar på fyra olika former av deltagande i daghem och förskola. Artikeln bidrar till att sätta barns deltagande i relation till en samhällskris som coronapandemin samt visar på ett mångfacetterat deltagande. Resultatet av studien kan få implikationer både på förhållningssätt och arbetsmetoder i samband med kriser.
\end{abstract}

\section{Children's participation in early childhood education settings during early outbreak of coronavirus in Finland and Sweden}

\begin{abstract}
The corona pandemic is a new social crisis that is sparsely researched, and different perspectives on the corona virus are needed. This article helps to deepen the knowledge of children's expression of the corona virus. It highlights staff's descriptions of children's expressions regarding the coronavirus outbreak in Finland and Sweden in early childhood education contexts in March 2020. The empirical material consists of 79 questionnaires from early childhood education staff. The concepts participation and resilience have been used as theoretical background and these are discussed in the article. The analysis highlights four different forms of participation in relation to the outbreak of the virus. The article contributes to putting children's participation in relation to a social crisis like the corona pandemic and shows a multifaceted participation. This can have implications both on attitudes and working methods in relation to crises.
\end{abstract}

\section{Inledning}

Coronapandemin är en ny samhällskris som är sparsamt beforskad, och olika perspektiv på coronaviruset behövs för att hantera en delvis ny vardag som uppstår, detta även för barn. Ett barnperspektiv, eller snarare ett tydligt iaktta- gande av vilka konsekvenser beslutsfattande har för barn, kan sägas ha varit frånvarande under den inledande delen av utbrottet i både Finland och Sverige, och barns perspektiv inte varit särskilt synligt vare sig i media (även om 
undantag finns) eller i forskning. Public service-bolagen i Finland och Sverige, YLE och SVT, har dock på olika sätt inkluderat barnperspektivet i sin produktion. Lilla Aktuellt på Sveriges Television har exempelvis gjort återkommande inslag med allt från enskilda barn, som berättar om sin situation, till inslag där barn får ställa frågor till statsministern om coronaviruset. BUUklubben på Svenska YLE har gjort informativa inslag om vad viruset är och hur vi som enskilda individer kan hantera det i vår vardag. Det har även förekommit tidningsartiklar och poddavsnitt riktade till vuxna gällande hur de kan prata med barn om coronaviruset, och också direkta myndighetsråd gällande hur man kan hantera barnens frågor kring viruset. Under arbetet med denna artikel har dock denna typ av inslag i medierna ökat. Detta gör att behovet av kunskap och fördjupad förståelse är stort när det gäller hur barn, och särskilt barn i daghem och förskola, berörs av pandemin.

Tidigare forskning inom främst medicin och psykologi har visat att negativa livserfarenheter (som till exempel naturkatastrofer, krig, fattigdom, klimatförändringar och pandemier) påverkar barns hälsa och välmående på kort och lång sikt (Masten och Barnes 2018). Detta i sin tur påverkar daghemmens och förskolors verksamhet och deras möjlighet att uppnå de centrala målen om lärande och omsorg för barn, när barnen kan bära på sådana livserfarenheter. I samband med kriser blir barns position extra sårbar (Amri m. fl. 2017, Last 1994, UNISDR 2015). Barn riskerar under kriser att bli särskilt beroende av vuxna och deras möjligheter att bli hörda och sedda riskerar att minska (Last 1994, Anderson 2005). Samtidigt är barn också aktiva, deltagande subjekt med möjlighet att genom sina handlingar medverka i hanteringen av utmanande situationer (Peek 2008). Dessa aspekter är relevanta att ha i beaktande när man tittar på hur pandemin uppfattas och uttrycks i kontexter där barn finns.

Vi argumenterar i denna artikel för vikten av att fånga upp barns sätt att uttrycka sig kring den pågående krisen. Att fånga upp barns sätt att uttrycka sig om krisen i form av deltagande i den lokala kontexten är ett sätt att erkänna barns deltagande som samhällsmedborgare. Deltagande i form av att på olika sätt uttrycka sig kring krisen ses som ett betydelsefullt element i att utveckla resiliens (här förstått som anpassningsförmåga eller motståndskraft vid motgångar) i krissituationer. Barns uttryck om virusutbrottet har i den här studien fångats upp av personalen i daghemsoch förskolekontext. I denna artikel används begreppet personal som ett sammanfattande begrepp för yrkeskategorierna förskollärare, lärare i småbarnspedagogik, barnskötare samt rektor.

Denna artikel ger ett barnperspektiv på coronaviruset i och med att personal vid daghem och förskolor har tillfrågats om hur barn i ord och handling uttrycker sig och tar till sig coronapandemin. (Begreppen för första utbildningsnivån för barn i åldrarna 1-6 år skiljer sig åt i de två länderna. I Finland används "daghem" och i Sverige "förskola", därav används båda begreppen i denna artikel.) Det är inte möjligt att i denna artikel studera barns utvecklande av resiliens per se, utan utvecklandet av resiliens vid kriser ses här vara avhängigt barns förutsättningar till aktivt deltagande i de miljöer där de vistas, såsom daghem och förskola. För möjlighet till deltagande behövs dock stöd från vuxna och från den omgivande kontexten. Därför har personal vid daghem och förskola en särställning i den mening att de att dels kan möjliggöra barns deltagande och därmed också på sikt, utvecklandet av barn resiliens, dels att de på nära håll har kunnat följa barns uttryck om viruset och coronapandemin.

Artikeln inleds med en beskrivning av kontexten för studien. Därefter följer en teoretisk bakgrund och forskningsgenomgång där begreppen deltagande och resiliens som kan bidra till en fördjupad kunskap om artikelns tema lyfts fram. Efter syfte och forskningsfrågor följer metodpresentation och därefter studiens resultat och diskussion. 


\section{Kontextbeskrivning}

Förskolans och daghemmets uppdrag som samhällsinstitution är att vara en plats där barns frågor och tankar ska utgöra en del av verksamhetens innehåll. Detta breda uppdrag gäller både i Finland och i Sverige (Grunderna för planen för småbarnspedagogik 2018, Läroplan för förskolan 2019). Nedan ges en översiktlig beskrivning av samhällskontexten i Finland och Sverige vid tiden för den empiriska studien (17-24 mars 2020), samt hur daghemsoch förskolevardagen tog sig nya uttryck i de två länderna.

Den finländska regeringen fattade den 12 mars beslut om åtgärder för att bekämpa smittspridningen av viruset. Distansarbete rekommenderades och återvändare från områden där smittan fanns var tvungna att arbeta på distans eller hålla sina barn hemma från förskola eller skola under två veckor. Den 16 mars konstaterade den finländska regeringen att undantagstillstånd rådde i samhället, vilket innebar att skolor, läroanstalter och universitet stängde och övergick till distansundervisning. Verksamheten inom småbarnspedagogiken fortsatte, men föräldrar som hade möjlighet att ordna vården av barnet hemma uppmanades göra det. Obekräftade beräkningar hävdar att ca 25 procent av barnen då deltog i daghemsverksamhet. Utbildningsstyrelsen gick även ut med rekommendationer för personalen inom småbarnspedagogiken. Den 17 mars anmodade regeringen för första gången i fredstid riksdagen att ta beredskapslagen i bruk. Den 22 mars initierades en informationskampanj för spridning av tillförlitlig information i sociala medier, vilket gjorde bekämpningen av coronaviruset till ett centralt innehåll i både traditionella och digitala medier.

Den svenska regeringen började fatta beslut med anledning av coronaviruset i mars 2020 då regeringen fattade beslut om att anpassa lagar och riktlinjer inför en eventuell skolstängning. Den 18 mars fattades beslut om att rekommendera distansarbete för gymnasieskolor, högskolor, universitet, yrkesutbildning och vuxenutbildning. Enligt medier beslöt en del kommuner att stänga förskolor för barn till arbetslösa eller föräldralediga vårdnadshavare på grund av personalbrist. 19 mars gav regeringen huvudmän möjlighet att stänga förskolor (fritidshem eller annan pedagogisk verksamhet) tillfälligt under extraordinära händelser (SFS 2020:148). Barn som behövde förskolans stöd på grund av fysiska, psykiska eller andra skäl, samt barn vars vårdnadshavare hade en samhällsviktig funktion, skulle erbjudas barnomsorg. Förskolorna har under hela denna tid varit öppna.

\section{Coronavirusets inverkan på barns vardagsliv}

Globalt har pandemin hanterats med skärpta råd om främst hygien och restriktioner när det gäller umgänget med andra människor, något som omfattat såväl barn som vuxna (WHO 2020). Finland och Sverige har i olika grad valt att tillämpa social distansering som ett sätt att bromsa smittspridningen för att det egna landets sjukvårdskapacitet skulle klara av att hantera virusutbrottet.

Beslut om social distansering har långtgående konsekvenser för barn, eftersom de påverkar deras vardag både direkt och indirekt (jfr. Brooks m. fl. 2020; Wang m. fl. 2020). Om eller när barn stannar hemma från daghem/ förskola kan detta få både fysiska och psykiska följder för dem (jfr. Brooks m. fl. 2020; Wang m. fl. 2020, Brooks m. fl. 2020). En pågående brittisk studie av hur familjer påverkas av pandemin visar att oro och rädsla är en dominerande konsekvens framför allt hos yngre barn (Weale 2020). Forskning om hur barns erfarenheter av pandemin kommer till uttryck i daghems- och förskolekontext saknas för närvarande helt.

\section{Tidigare forskning och teoretisk bakgrund}

I detta avsnitt redogör vi för tidigare forskning kring barn som är av relevans för studien samt presenterar studiens centrala begrepp. Barndomssociologin som perspek- 
tiv på barndom ramar in studien och inom den betonas vikten av att se barndom som en social konstruktion och inte enbart som ett biologiskt fenomen (James och Prout 2015). Barndomen som ett steg mot vuxenlivet, där barn ses som en social grupp i samhället, menar James och Prout (2015) ska ses som intressanta i sig, inte för att de är på väg till något annat. Detta innebär bland annat att barn bör studeras och betraktas som beings, och inte som becomings, vilket i vår studie inneburit att vi ser barn som aktiva samhällsmedborgare varsderas deltagande är viktigt att inkludera i samhällsdebatten idag för att förstå samhällets alla delar (jfr. Jans 2004). Detta barnperspektiv, där vuxna (forskare) studerar och analyserar barns liv och erfarenheter, innebär också att kontextualisera såväl barns utsagor som vuxnas utsagor om barn.

För att förstå barns uttryck om coronavirusets utbrott i Finland och Sverige i daghemsoch förskolekontext använder vi begreppet deltagande för att analysera det empiriska materialet och begreppet resiliens för att diskutera barns deltagande på ett bredare sätt. Användningen av begreppet deltagande innebär att vi undersöker vilka möjligheter barn ges till deltagande i daghems- och förskolekontext (här utifrån personalens tolkningar), och att deltagande ses som möjlighet till att utveckla resiliens. Vår tolkning av begreppet resiliens förutsätter att barn ges möjlighet till deltagande på samhällsnivå. Deltagande och resiliens används som begrepp på olika sätt i artikeln, och med delvis olika syfte. Deltagande är det analytiska begrepp som används för att bearbeta och analysera det empiriska materialet. Begreppet resiliens används i diskussionen av studiens resultat med avseende på hur begreppet kan förstås i relation till deltagande. Detta speglar en sociologisk grundad förståelse av barn där resiliens förstås som en relationellt och systemiskt grundad förmåga (jfr. Masten och Barnes 2018).

\section{Barns deltagande}

Barns möjlighet till deltagande i samhället har under de senaste årtiondena ökat, bland annat genom ratificeringen av FNs konvention om barnets rättigheter (Förenta Nationerna 1989). I studier av barn och barndom diskuteras betydelsen av barns samhällsdeltagande och hur det möjliggörs (se t.ex. James och James 2008; James 2009). Nationella och internationella politiska agendor har förvisso fokuserat på frågor om barn och barns rättigheter men däremot finns betydligt större frågetecken kring vilka möjligheter barn ges för att själva kunna utöva deltagande i frågor som rör dem och de samhällen de lever i (Aitken 2013). Det är därför viktigt att betrakta barn som deltagare i samhället och i världen.

Johansson (2009) menar att idéer om barnet som samhällsmedborgare inte behöver ses abstrakt, utan snarare som en del av det konkreta samspelet i daghemmet och förskolan samt en balans mellan det individuella och de kollektiva kombinerat med solidaritet och ansvarstagande. Dolk (2013) beskriver hur deltagande i förskolan ger möjlighet till att aktivt vara med och skapa relationer och normer samt påverka ramarna kring en pedagogisk verksamhet. Enligt Dolk kan delaktighet på detta sätt vara nära knutet till demokrati och samhällsmedborgarskap.

De etiska och demokratiska frågorna i det vardagliga samspelet i daghemmet och förskolan har alltså att göra med vilken människosyn, förståelse för sig själv och andra i världen som barn ges möjlighet att utveckla. Enligt Jans (2004) kan ett barncentrerat medborgarskap ("children-sized citizenship") definieras utifrån fyra dimensioner; medborgarskap som rättighet, medborgarskap som ansvar, medborgarskap som identitet och medborgarskap som deltagande. Medborgarskap som deltagande är enligt Jans (2004), den viktigaste dimensionen för att förstå ett barncentrerat medborgarskap. Utgångspunkten är att barn påverkas av samhället de är en del av, samtidigt som de är aktörer som påverkar samhället, givet att 
de des möjlighet att göra detta genom deltagande. I definitionen ligger även en bredare syn på medborgarskap där medborgarskap ses som en dynamisk och pågående lärandeprocess. På samma sätt som vuxna och barn kan vara delaktiga i hur barns barndomar skapas, ingår de i en lärandeprocess som ger innebörd till vad medborgarskap kan innebära för barn respektive vuxna. Det är framför allt denna dimension som vi har använt oss av i vår studie. Wood (2014) hävdar i linje med detta att barns aktiva deltagande i relation till lärande och barns möjligheter till agens förutsätter förmåga till lärande (att undervisa sig själv och att utveckla reflexivitet och metakognitiva förmågor). Barns agens, eller som här deltagande, handlar om motivation till lärande, att bli mer kompetent och kunskapsvillig och att hantera social dynamik i institutionella och mellanmänskliga sammanhang. Agens kan utifrån denna syn på lärande förstås som att placera sig själv i aktivt deltagande.

\section{Deltagande som förutsättning för utvecklande av resiliens}

Utvecklingen av barns resiliens sker i samspelet mellan barn och betydelsefulla vuxna i deras vardag. Daghemmet/förskolan är i det här avseendet särskilt viktiga kontexter. Från att tidigare ha betraktats som en individuell och psykologisk förmåga, har förståelsen av resiliens genom de senaste årtiondenas tvärvetenskapliga forskning kommit att vidgas. Resiliens utvecklas i kontextuellt förankrade processer. Ungar (2011) beskriver resiliens som förmågan att mobilisera resurser (psykologiska, sociala, kulturella eller fysiska) för att upprätthålla välmående och pekar på betydelsen av att miljön runt barn erbjuder möjligheter för dem att navigera på ett sätt som stärker denna förmåga. När det gäller enskilda individer är resiliens relationellt konstituerad, det vill säga tätt kopplad till individens relationer till andra människor, system eller processer (Masten och Barnes 2018). Resiliens kan grovt definieras som ett systems förmåga att framgångsrikt an- passa sig till utmaningar som hotar dess funktion, existens eller framtida utveckling (Masten och Barnes 2018). Även om enskilda individers resiliens påverkas av personlighet och kognitiv kapacitet, spelar stödjande relationer en avgörande roll. Nära anknytning till föräldrar och andra vårdare utgör skyddande faktorer, särskilt för yngre barn. Speciellt under utmanande omständigheter är de vuxnas förmåga att balansera utvecklande och skyddande faktorer av vikt. Freeman, Nairn och Gollop (2015) argumenterar för att barns röster måste tas tillvara i samband med kriser:

In disaster research such an approach is especially relevant as it positions children not merely as vulnerable recipients in need of protection but also as competent social actors with voice and agency, capable of understanding and acting in response to disasters. (s.104)

Det här innebär att barns möjligheter att uttrycka sina erfarenheter i samband med kriser är tätt länkade till de vuxnas förmåga att fånga upp situationen på ett för barnet konstruktivt sätt. När det gäller barn som spenderar en stor del av sin vakna tid på daghem/förskola blir följaktligen personalens förhållningssätt av stor betydelse.

Genom att möjliggöra barns deltagande i olika faser av en kris kan deras resiliens stärkas (Prilleltensky m. fl. 2001; Sanson, Van Hoorn och Burke 2019) och barns självtillit och välmående påverkas. Att bidra och vara delaktig i ett sammanhang stärker tilltron till den egna förmågan och upplevelsen av kontroll. Även Sanson, Van Hoorn och Burke (2019) lyfter fram betydelsen av att möjliggöra deltagande och engagemang hos barn för att skapa resiliens.

Tidigare forskning om hur vuxna kan möta barns oro, ångest och rädsla i samband med kriser visar på betydelsen av trygga relationer och pedagogiska närmandesätt som öppnar upp för kreativitet och lek. Nijhof med flera (2018) visar på leken som ett betydelsefullt 
element i stärkandet av barns resiliens, eftersom leken bland annat stöder bearbetandet av kognitiv och emotionell information, stimulerar kreativitet och problemlösning, stärker förmågan att hantera stress och motgångar. Bateman, Danby och Howard (2013) studerar barn i Nya Zeeland som har erfarenhet av jordbävningar och i studien riktar de primärt in sig på att analysera barns lek i relation till det, och också sett ur perspektivet barns aktiva deltagande. Bateman med flera (2013) menar att leken är en plats där barn kan göra världen mer begriplig genom att pröva och utforma roller, identiteter och erfarenheter. Resultaten belyser hur leken blir en plats att uttrycka sig kring de olika akuta delarna i jordbävningshändelsen - som exempelvis att fixa sådant som gått sönder. Bateman med flera anser att fantasilekar ("pretend play") gör det möjligt för barnen att återuppleva och bättre försöka förstå sina traumatiska upplevelser av jordbävningen.

Genom att lyssna till barns röster och skapa möjlighet för dem att engagera sig aktivt, bidrar centrala vuxengestalter till barns känsla av kompetens både som individ och som gemenskap. Detta stärker barns förmåga att tackla och anpassa sig till kriser på flera plan. På det individuella planet kan det innebära att stärka barns självreglering (känslomässig, kognitiv och beteendemässig) och att stödja värden som empati, social rättvisa och kreativitet. På det interpersonella planet kan det betyda att stärka färdigheterna att samarbeta och att hantera konflikter. På det sociala/medborgerliga planet kan det handla om att stärka förmågan till aktivt medborgarskap.

Pfefferbaum, Pfefferbaum och Van Horn (2018) menar att barns deltagande i hanteringen av kriser är betydelsefullt både för barnen själva och samhället i stort. Ur ett samhällsperspektiv leder barns deltagande till förbättrade sociala nätverk och ökad beredskap. Även Peek (2008) hävdar att vuxenvärlden måste befrämja barns resiliens genom att skapa möjligheter för deltagande i såväl förebyggandet som hanteringen och återhämtningen vid kriser.

Mot bakgrund av de här resonemangen är det angeläget att uppmärksamma barns sammanhang i samband med coronavirusets utbrott och studera deras möjligheter till deltagande. Detta kan i förlängningen bidra till utvecklande av resiliens. I den här studien speglas begreppet resiliens mot resultatdelens analyskategorier som ett sätt att fördjupa förståelsen för resultatet av barns deltagande i daghem och förskola.

\section{Syfte och forskningsfrågor}

Det övergripande syftet med den här artikeln är att undersöka barns uttryck i daghem och förskola i samband med coronavirusets utbrott i Finland och Sverige. Av metodskäl studeras detta genom att analysera personalens utsagor. Mer precist är syftet att synliggöra olika former av barns deltagande. I artikeln diskuteras hur deltagande ger möjlighet för barn att utveckla resiliens i krissituationer.

Studiens forskningsfrågor är:

- Vad beskriver personalen att barn uttrycker om coronavirusets utbrott?

- Vilka olika former av deltagande synliggörs i barns uttryck?

\section{Metod}

För att besvara forskningsfrågorna har kvalitativ datainsamling bedömts ge ett relevant empiriskt material. Kvalitativa data ger röst åt deltagarna kring ett samhällsfenomen och möjliggör analys av kvalitativa aspekter av fenomen som går bortom siffermätning (Cohen, Manion och Morrison 2018). I kvalitativa studier är det just de olika egenskaperna hos ett fenomen som lyfts fram och som ges utrymme. När det gäller barns sätt att uttrycka sig och vara deltagande i relation till coronaviruset är det inte primärt intressant i detta läge att räkna hur många utsagor av en viss sort som finns, utan fokusera på att lyfta fram de mångfacetterade sätt som barn deltar i sin samtid på. Kvalitativa metoder ger insyn i barns och 
ungas "upplevda verkligheter", och här är de förmedlade av de vuxna som arbetar med barnen (Hatch och Coleman-King 2015: 441). Hatch och Coleman King (2015) menar också att användning av kvalitativa metoder är ett ovärderligt sätt att beforska barn och unga på genom att metoderna ger möjlighet att närma sig barns egna röster. Amri med flera (2017) förordar också metoder som är lätta att upprepa i olika kontexter, till exempel enkäter, för att utforska barns deltagande i uttryck om och kring hanteringen av kriser.

Materialet till den här studien har samlats in genom en kvalitativ enkät riktad till förskoleoch daghemspersonal i Finland och Sverige. Enkäten sammanställdes gemensamt av artikelförfattarna och publicerades på sociala medier mellan den 17 mars 2020 och den 24 mars 2020. Enkäten spreds via både författarnas privata facebook- och instagramsidor och i två olika öppna grupper för förskole- och daghemspersonal på sociala medier varav en i Finland och en i Sverige Den skickades även till relevanta nyckelpersoner i författarnas nätverk per e-post. Som enkätverktyg användes webbverktyget e-lomake.

Metoden som använts innebär begränsningar. Den valda metoden, som i detta läge är den enda möjliga, gör att det är personalens tolkningar av barns sätt att delta som är forskningsbart och som vi har valt att förstå som barns deltagande, även om deltagandet inte studerats på plats. Detta relateras till diskussionen om barnperspektiv och barns perspektiv. Enligt bland annat Halldén (2003) är ett barnperspektiv att vuxna tolkar barns liv, erfarenheter och tankar, och förmedlar dessa, medan barns perspektiv är när barn själva ger uttryck för sina erfarenheter och tankar. Forskningens eviga dilemma är att barnperspektiv är förhärskande, trots att många som forskar om barn försöker närma sig barns perspektiv. Det är dilemmat även i den här studien och det är således personalens tolkningar av barns uttryck om coronaviruset i sin vardag som analyseras. Trots denna begränsning väljer vi att förstå det som barnens röster. Det gör vi på grund av att det inte finns andra sätt att beforska detta på i och med att sociala begränsningar råder. Vi ser också att det alltid, oavsett metod, kommer att vara vuxnas tolkningar som förekommer gällande att besvara forskningsfrågor som här ställs. Då menar vi att personalen, som känner barnen bäst, är bäst lämpade att göra dessa tolkningar som vi vill lyfta fram här. Det innebär ett raster och en förförståelse av en mängd olika aspekter av både barnen och pandemin. Det försöker vi i de analyser som görs vara reflexivt medvetna om.

Enkäten som sammanställdes bestod av tio frågor, varav fyra var bakgrundsfrågor och sex frågor handlade om barnens uttryck om viruset och personalens sätt att bemöta barnen. I den här artikeln är fokus enbart på hur förskolepersonalen tolkar barnens uttryck om viruset och hur de förstås av personalen som svar i enkäten. Valet av arbetssätt berodde på att barnen inte själva kunde intervjuas på grund av rådande omständigheter och rekommendationer kring social distansering.

De mest centrala frågor som analyserats till denna artikel var:

- Vilka frågor eller kommentarer har barnen gällande coronaviruset?

- Hur många av barnen har haft frågor eller kommentarer?

- Hur har ni hanterat frågorna?

- Vilka strategier har barnen uttryckt gällande hanteringen av viruset eller eventuellt insjuknande?

Det empiriska materialet består av alla svar som inkom på dessa frågor; totalt 79 stycken (32 stycken från Sverige, 46 stycken från Finland samt en (1) som inte uppgett land). Huvuddelen av de som har svarat var förskollärare/lärare inom småbarnspedagogik (Sverige 72 \%, Finland 67 \%). Övriga svarande består av barnskötare, rektor/föreståndare samt ett fåtal övriga. $46 \%$ av informanterna har 20 år eller längre erfarenhet av att arbeta i förskola/daghem. Daghemmen/förskolorna som informan- 
terna representerar i Finland är främst belägna på landsbygden (39\%) eller i mindre städer (30 $\%)$ medan det i Sverige är en relativt jämn fördelning mellan landsbygd och stad.

\section{Analysmodell}

Det empiriska materialet har analyserats med inspiration från hermeneutisk, reflexiv tolkning (Alvesson och Sköldberg 2017; Furu 2011) i flera steg. Med utgångspunkt i en trippelhermeneutisk rörelse fördjupades gradvis tolkningen från en fältnära deskriptiv förståelse av forskningsfenomenet till en kritiskt präglad förståelse. Dessutom lades ett fjärde steg till i analysprocessen, nämligen den reflexiva tolkningen. Alvesson och Sköldberg (2017) presenterar begreppet kvadrohermeneutik som term för den här formen av trippelhermeneutisk tolkningsprocess driven och genomsyrad av reflexionens princip.

I det första steget läste samtliga forskare enkätsvaren varför sig för att urskilja tematiska mönster. Syftet med detta förfarande var att garantera bedömarinterreliabilitet. Den här processen föregicks av en inledande utveckling av syftet och forskningsfrågorna, så att dessa kunde vara i förgrunden för varje forskares inledande läsning av materialet. Eftersom var och en av forskarna har skiftande kunskapsbakgrund och forskningsfördjupning har metoden här drag av ett bricolage (jfr. Denzin och Lincoln 2018). Det här innebär att en mångfald av närmandesätt ger möjlighet till en rikare beskrivning och förståelse av forskningsfenomenet, jämfört med om fenomenet betraktas enbart i ett perspektiv. I den gemensamma genomgången efter en första läsning av materialet framträdde ändå stor samstämmighet kring större centrala tematiska helheter i materialet och utsagor som kunde exemplifiera dem. I det andra steget läste forskarna materialet ytterligare en gång till med studiens teoretiska begrepp och teorier som utgångspunkt, och dessa formulerades som deltagande och resiliens. Det tredje steget i den kvadrohermeneutiska modellen innebar en slags mot- läsning av materialet och man sökte efter eventuella luckor, tystnader, spänningar och motberättelser i det empiriska materialet. Det fjärde steget innebar en avslutande reflexiv tolkning där forskarna förhöll sig medvetet till sitt eget sätt att arbeta och till vad som blev möjligt i ett sådant sammanhang. I detta steg har även syftet och forskningsfrågorna utvecklats ytterligare. Alvesson och Sköldberg (2017) beskriver de grundläggande elementen i en reflexiv tolkning som å ena sidan dekonstruktion, defensivitet, destabilisering och å andra sidan rekonstruktion och representation. De förra pekar på osäkerheter, problem och begränsningar i forskningen som projekt, och de senare odlar öppenhet, kreativitet och mångfald, samt bäddar för utveckling av forskningspraxisen. Målsättningen har i arbetet med analysen i den här studien varit att hitta en balans mellan de båda elementen i en reflexiv tolkning.

\section{Etiska aspekter}

I enlighet med riktlinjerna för god forskningssed (Vetenskapsrådet 2017; TENK, 2012) har deltagarna skriftligt informerats om studiens syfte; att deltagandet är frivilligt och att samtycke till studien sker genom besvarande av enkäten. Deltagarna informerades även om att inga obehöriga ges till tillgång till materialet. All data är anonymiserade och behandlas konfidentiellt, det vill säga att enskilda personer inte går att spåra i resultatredovisningen som presenteras på aggregerad nivå. Möjligen kan enskilda personer känna igen citat utifrån sådant de själva skrivit i enkäten, men dessa länkas inte till några personuppgifter i redovisningen av resultaten.

\section{Trovärdighet och pålitlighet}

I en kvalitativ enkätundersökning kan kvalitetskriterier från både kvalitativ och kvantitativ forskningsdesign vara tillämpbara för att diskutera studiens kvalitet.

Enkätfrågorna formulerades av forskarna tillsammans utifrån studiens syfte, frågeställningar och inledande teoretiska idéer. 
Datainsamlingen genererade ett omfattande empiriskt underlag vilket är ett tecken på att personalen uppfattat enkätfrågorna som relevanta i förhållande till den rådande situationen i förskola och på daghem. Det är dock personalens förmedlade utsagor av barnens uttryck i förhållande till coronaviruset som analyserats här. Det är därför troligt att också andra uttryck förekommer bland barnen, men som inte uppmärksammats av personalen och som riskerar att bidra till att resultatet inte är helt tillförlitligt. Vår bedömning är att resultatet är tillräckligt tillförlitligt i och med att alla forskarna bedömt materialet som rimligt och att det också funnits en samstämmighet i materialet.

De digitala forum och e-postadresser som använts för att sprida enkäten var direkt riktade till personal verksamma i förskola och daghem, vilket styrker att enkäten besvarats av representanter från den tilltänkta målgruppen. Enligt David och Sutton (2011) finns dock alltid ett urvalsproblem med digitala enkäter därför att de endast besvaras av de som har tillgång till, och nödvändiga kunskaper att hantera, tekniken.

Resultaten kan ses som trovärdiga och överförbara till andra daghems- och förskolekontexter då deltagande och resiliens som teoretiskt raster genererat mönster för hur barns uttryck även av andra krissituationer kan förstås.

\section{Resultat}

Personalens förmedling av barnens uttryck ifrån såväl Finland som Sverige visar på olika teman gällande barnens deltagande i relation till virusutbrottet, och att dessa tenderar att vara liknande i de båda länderna. Utgångspunkten i analysen har varit att se "uttryck" som ett konkret sätt att förstå deltagande. Barnens kontextuella deltagande kring coronaviruset handlar övergripande om följande teman: 1) deltagande relaterat till hälsoaspekter av coronaviruset, 2) deltagande relaterat till existentiell oro samt visa omsorg, 3) deltagande relaterat till sociala inskränkningar och förändrade rutiner samt 4) deltagande genom lek, skapande och humor.
En del av personalen (omkring en femtedel) uppger att barnen inte haft några kommentarer alls om corona. Yngre barn beskrivs ha färre frågor och funderingar om själva viruset, men deras frågor kan gälla förändrade rutiner eller att vänner inte är närvarande på daghemmet eller förskolan.

\section{1) Deltagande relaterat till hälsoaspekter av coronaviruset}

Utifrån personalens svar om vad barnens kommentarer och funderingar handlar om framkommer att barnen pratar om corona och relaterar det i stor utsträckning till hälsa. Barnen pratar exempelvis om att corona är ett virus och hur detta virus bäst ska hanteras för att inte de själva, vänner eller familjemedlemmar ska bli sjuka. De flesta av dessa kommentarer handlar om vikten av att tvätta händerna och hur händerna bör tvättas. Något barn hade tips på att tvätta händerna lika länge som det tar att sjunga Blinka lilla stjärna. Andra undrade varför de skulle tvätta händerna hela tiden med vissa sa saker som "tvättar vi inte händerna - då kommer viruset". Även hur man borde hosta för att inte sprida viruset togs upp och personalen beskrev att barnen visade hur man ska hosta i armvecket. Någon undrade också om man överhuvudtaget fick hosta.

När det gäller barns förståelse av situationen och hur det uttrycks berättar personalen bland annat om följande kommentarer som refererar till faktakunskap. Ett barn ska ha sagt:

Det finns ett virus som heter Corona. Det är runt med taggar på. Det kan hoppa in i näsan så blir vi sjuka. Därför måste vi tvätta händerna med tvål.

Personalen beskriver att barnen också sinsemellan kan diskutera om ett jättefarligt virus som man dör i.

Ett återkommande mönster i materialet är att barnens deltagande i samtalen kring corona relaterar till frågor om all sjukdom är corona. I materialet finns inget uttryck för att barnen skulle använda sjukdomens namn, det vill säga 
covid-19, utan corona är det som förekommer. Vissa frågor och påstående som barnen har såsom att om viruset dör om man tvättar händerna och att man ska hålla sig hemma om man är sjuk är mycket lik den informationen som framförs i media av olika experter och som även personalen säger sig förmedla till barnen. En vanlig strategi som personalen beskriver är att diskutera fakta kring viruset i samband med när barnen ställer frågor. Andra frågor om själva viruset handlade om hur det egentligen ser ut:

\section{- Är det grönt?}

- Hur ser man om viruset kommer, kan man se det?

- Finns det redan i närheten?

- Om man blir sjuk, hur sjuk blir man då?

Personalen beskriver att vissa barn tror att smuts och skräp ger corona eller att man får corona av att spela brädspelet Corona.

\section{2) Deltagande relaterat till existentiell oro samt visa omsorg}

Framträdande i personalens beskrivningar av barnens kommentarer var även rädsla och oro men också att visa omsorg om andra i relation till viruset. Det förstås här som deltagande av existentiell karaktär. Många barn uttrycker en stark oro kring situationen där rädslan framförallt är kopplad till att mista familjemedlemmar. Personalen beskriver att barn kunde ha corona som förklaringsmodell för sina föräldrars beteende, exempelvis om de var arga eller stressade, så kanske det berodde på viruset. Personalen beskriver att de har mötts av kommentarer som: "Jag är rädd för min mammas skull" eller "Jag är rädd för att vår baby därhemma har corona". Frågor som

\footnotetext{
- Vem hittade på corona?

- Hur får man död på corona?

- Kan du dö i corona?

- Vad händer när man dör?

- Hur kan man rädda någon så att den inte dör?
}

var också frågor som förekom i materialet och som här tolkas som oro, rädsla och frågor om liv och död. De här frågorna ligger nära den förra formen av deltagande som beskrivs ovan och som berörde hälsa.

Ovanstående kommentarer är exempel på uttryck om existentiella frågor som personalen förmedlat från sina barngrupper. Frågorna handlar om virusets uppkomst, hur man kan utplåna det samt frågeställningar om döden. Frågorna och kommentarerna om döden handlar ofta om vad döden innebär, om man kan rädda någon från döden, och om vad som händer om någon närstående dör, såsom uttrycks nedan:

Om jag blir sjuk ska jag spela dator hela dagen. Om mamma och pappa dör blir jag ensam.

Ovan beskrivs ett barns fråga om närståendes död och vad som händer ifall både mamma och pappa dör med den eventuella ensamhet som då kan komma att uppstå. Barn kunde också ge uttryck för rädsla i form av krig och undergång. I nedanstående uttryck kopplas denna undergång till fladdermössen.

Att alla dör av det. Det är som ett krig. Jag är rädd för min mammas skull, det kommer från fladdermöss.

Även rädsla för människor från andra länder framträder i materialet, inte minst rädslan för människor från Kina. Enligt en i personalen förekom den här typen av frågor i samtal kring coronaviruset:

"Jag HATAR alla kineser!"Jag frågar vad hen menar och hen svarar: "min mormor säger att det är kinesernas fel att det finns corona så jag HATAR dem!"

Ovanstående citat, menar vi kan förstås mot bakgrund av de diskurser i media och omgivande samhälle som, inte minst i inledningen av utbrottet, kom att handla om viruset som ett kinesiskt fenomen som spreds från djur till människa. Inte minst fladdermössen utmåla- 
des som värddjur för viruset. Rädslan för Kina och kineser, vilket barnet ovan ger uttryck för, samt uttalanden från Donald Trump om att vi inte kommer att klara coronaviruset visar att barnen inser att detta är något som berör människor i flera delar av världen.

Ytterligare uttalanden som handlar om oro och omsorg avsåg husdjur, gamla personer och äldre släktingar såsom mormor, farfar och farmor. Inga kommentarer i det här materialet handlar dock uttryckligen om barnens egen död i relation till viruset.

\section{3) Deltagande relaterat till sociala inskränkningar och förändrade rutiner}

Många uttalanden av personalen anger att barnen på olika sätt uppmärksammat och kommenterat de sociala inskränkningar som situationen medfört. Även de yngsta barnen kommenterar enligt personalen att det är betydligt färre barn på förskolorna. De frågar efter sina kompisar som är hemma och en del av barnen beskrivs av personalen som något vilsna. Äldre barn kunde dra slutsatser som att ifall någon hostar är det corona och att de barn som inte är på förskolan har drabbats av viruset. Sådana uttryck som personalen ger uttryck för är bland annat:

Flera barn är lite rädda och vilse mest för att verksamheten är så annorlunda och kompisarna är hemma. De har undrat varför kompisar är borta. Ett automatiskt antagande har varit att kompisarna har drabbats av coronaviruset.

Ett annat mönster i materialet är barns undran över var kompisarna var. En del barn ger uttryck för att de tror att kompisar är hemma för att de har fått coronaviruset. Gemensamt för Finland och Sverige är att barnen beskriver att deras tillvaro både på förskolan och i hemmet påverkas mycket av begräsningen av sociala relationer; att inte kunna gå till fritidsaktiviteter, att inte kunna hälsa på kompisar och att inte kunna hälsa på sina äldre släktingar. Ett barn berättade att man inte fick spela hockey mer.
Ytterligare aspekter är att omsorgen kan förändras genom nya rutiner. Ett exempel är att social distansering kan innebära att närheten mellan personalen och barnen får sättas på vänt för att undvika smitta. Exempel på detta är ett barn som frågar personalen: "Är det corona idag med, ånh nej jag som ville kramas!"

Ytterligare ett exempel på förändrade omsorgsrutiner kretsar kring den nya matsituationen på förskolan och att barnen inte längre får ta mat själva. Barnen har reagerat på detta och också på varför de inte får göra "high five" när de kommer till förskolan.

De pratar om de bilder vi satt upp som handlar om handtvätt och virus. De får inte heller ta mat själva längre vilket de är vana vid så vi pratar om hur virus och bakterier sprids.

\section{4) Deltagande genom lek, skapande och humor}

Resultaten visar även att i denna ovanliga situation pågår en vardag på förskolor och daghem där lek, skapande och humor influeras av ett ovanligt innehåll, nämligen coronaviruset. Ett exempel på detta är i de fall verksamheterna beskriver att de arbetar med att kommunicera på fler sätt än med det verbala språket med barnen. Ett exempel på det är att arbeta med skapande aktiviteter, ibland med anknytning till fakta om corona. En personal beskriver:

Vi har läst boken Ingrid och Basiluskan och låtit barnenen rita och berätta om Corona-basiluskan för att eventuellt lätta på tankar hos barnen.

I det material som analyserats i den här studien, framträder även coronaviruset i barns lekar. Personalen har fångat upp att sjukhuslekar har ökat och att barnen lekt att de haft coronaviruset och att de blivit friska av sprutor.

I förrgår lekte två barn med lego. Min kollega ser hur de lägger alla figurer på golvet, i en lång rad. Hon frågar dem vad de leker: Dom har dött för dom har corona. 
Att använda leken som strategi relaterar till det tidigare temat om existentiella frågor, eftersom lekarna handlar om att bli frisk, dö eller drabbas av corona på ett dramatiskt sätt. Barnen leker också corona genom tafatt, vilket beskrivs nedan:

Barnen har själva hittat på en coronalek, samma som tafatt men där fasttagaren är corona och ska ta fast de andra tills att alla fått corona.

Leken blir här på sätt och vis en strategi för att uttrycka sig kring och hantera en samhällskris, oro och omvälvande händelser (Bateman, Danby och Howard, 2013).

\section{Resultatsammanfattning}

Resultatet illustrerar barns olika sätt att uttrycka sig om den nya, okända och ofta kraftigt förändrade vardag som de själva, deras föräldrar, släktingar, vänner och personal befinner sig i.

Barnens deltagande sammanfattas i fyra former av deltagande; deltagande relaterat till hälsoaspekter av coronaviruset, deltagande relaterat till existentiell oro samt visa omsorg, deltagande relaterat till barns sociala inskränkningar och förändrade rutiner samt deltagande genom lek, skapande och humor.

Gällande deltagande relaterat till hälsoaspekter av coronaviruset lyfter personalen fram att barnen visste ganska mycket och att de ville ta reda på mer. Det här kan ses som ett uttryck för barns deltagande framförallt genom att svara på frågor och förmedla fakta. Detta speglar en syn på barn som aktiva och kunskapssökande. Barns deltagande relaterat till existentiell oro samt att visa omsorg är en central aspekt i studien. I några fall uppger personalen att barnen inte har ställt frågor om själva viruset, men att de ändå märkt av situationen och reagerat på den. Studien visar vidare på barns deltagande relaterat till sociala inskränkningar och förändrade rutiner och exemplifieras genom att barnens lekkamrater inte är närvarande eller att de inte kan delta i fritidsaktiviteter. Barns deltagande påverkades även av förändrade rutiner, exempelvis att den fysiska närheten begränsas och att det är ökat fokus på hygien. I fråga om deltagande genom lek, skapande och humor visar sig leken vara ett fjärde sätt för barn att uttrycka sig kring den nya situationen.

\section{Diskussion}

Det övergripande syftet med den här studien har varit att undersöka barns uttryck i samband med coronavirusets utbrott i slutet av mars 2020 i Sverige och Finland. Syftet har mer precist varit att synliggöra former för barns deltagande samt diskutera hur deltagande ger möjlighet att förstå barns utveckling av resiliens under den pågående pandemin.

Resultatet visar att barns uttryck kring coronaviruset är mångfacetterat och manifesterar sig genom olika former av deltagande. De analyser som här gjorts visar på fyra former av deltagande. I artikelns teoretiska bakgrund beskrevs att Jans (2004) menar att den viktigaste dimensionen för att förstå barn som samhällsmedborgare är den som handlar om medborgarskap som deltagande, och av den anledningen har det varit intressant att $\mathrm{i}$ analyserna lyfta fram hur deltagande är format i kontexten daghem och förskola, och i den här tiden. En slutsats som kan dras är att i relation till coronapandemin kan dessa fyra olika slags sätt att delta vara barns sätt att visa på medborgarskap. De olika formerna av deltagande som här presenterats ger förutsättningar för att förstå hur barn relaterar till den pågående pandemin i omvärlden (jfr. Johansson 2009).

Att förstå barns uttryck av ett virusutbrott är intressant för att både visa på att barn uttrycker sig om utbrottet genom olika slags deltagande, men också att sådan fördjupad kunskap i förlängningen kan bidra till att utveckla förståelsen av barns mångfacetterade medborgarskap (jfr. Nijhof m. fl. 2018; Bateman m. fl. 2013).

När det gäller kopplingen mellan deltagande och resiliens kan diskuteras om barn som har möjlighet till mångsidigt deltagande i en kontext i högre grad lär sig att ge uttryck 
för sina erfarenheter och därigenom får bättre förutsättningar att utveckla resiliens (jfr. Peek 2008, Pfefferbaum, Pfefferbaum och Van Horn 2018). Mot bakgrund av studien vill vi lyfta fram ett resonemang om att deltagande för barn är en förutsättning att utveckla resiliens, samtidigt som det kan det vara så att resilienta barn redan har getts möjlighet att utveckla kompetens för att bli delaktiga i verksamheten. Ur ett likabehandlingsperspektiv är det därför viktigt att alla barn ges möjlighet till deltagande för att få likvärdiga möjligheter att utveckla resiliens. Detta eftersom det finns en tydlig koppling mellan barns deltagande och resiliens med ett utvecklat medborgarskap (jfr. Sanson, Van Hoorn och Burke 2019).

Tidigare forskning beskriver resiliens som en förmåga att mobilisera resurser (psykologiska, sociala, kulturella eller fysiska) (Ungar, 2011) och Freeman, Nairn och Gollop (2015) hävdar att barns röster måste tas tillvara $\mathrm{i}$ samband med kriser som ett sätt att möjliggöra utvecklade av resiliens. Den här studien bidrar med kunskap om hur barns uttryck om coronapandemin fångats upp av personalen vilket möjliggjort barns deltagande i olika faser (Prilleltensky m. fl. 2001; Sanson, Van Hoorn och Burke 2019). I linje med de resonemang som förs av Pfefferbaum, Pfefferbaum och Van Horn (2018) och Jans (2004) visar denna studie att barns deltagande i kriser är betydelsefullt såväl för barnen sjäva som för samhället i stort.

Vi har i denna artikel understrukit vikten av att uppmärksamma barns sätt att uttrycka sig om den pågående krisen och därigenom bekräfta barns deltagande som samhällsmedborgare. Resultaten visar på barns mångfacetterade deltagande, genom att exempelvis barnen använder och delar med sig av sina kunskaper, uttrycker existensiella frågor genom lekar och att visa omsorg om andra. Det här kan tolkas som att barn kan utveckla resiliens genom att på ett mångfacetterat sätt få delta i en verksamhet i samband med en samhällskris som coronapandemin.

\section{Metoddiskussion}

Den digitala enkäten möjliggjorde en snabb datainsamling, vilket ses som en stryka för att kunna beforska aktuella samhällsfenomen, som varar en relativt kort tidsperiod, såsom coronautbrottet. Att enkätens huvudfrågor var öppna, möjliggjorde även att personalen med egna ord kunde återge barnens frågor och funderingar. En möjlig risk med detta är dock att personalens uppgifter är färgade av rådande samhällsdiskurs om utbildning, barn och barndom. Resultaten visar dock nyanserade, utförliga beskrivningar från personalen som representerar en stor demografisk och geografisk spännvidd i såväl Finland som Sverige.

\section{Implikationer av studiens resultat}

Den här artikelns resultat kan bidra till att ge personal inom daghem och förskola kunskap om hur barns deltagande i förhållande till den rådande samhällskrisen kan förstås. Resultaten kan också ge insikter om vilka olika slags deltagande barn utövar med avseende på virusutbrottet, och vilket slags frågor som kan uppkomma. Personal kan också utifrån resultatet förbereda och ta initiativ till samtal och pedagogiska närmandesätt som uppmuntrar till uttryck. Detta för att möjliggöra barns aktiva deltagande och därigenom stärka deras möjligheter att utveckla resiliens.

\section{Fortsatt forskning}

För närvarande saknas forskning på en rad olika punkter med koppling till coronaviruset och hur viruset påverkar barn på olika sätt. I arbetet med denna studie har behovet av forskning om hur personal i pedagogiska kontexter kan bemöta barn i samband med en samhällskris som coronaviruset. Fortsatt forskning som behövs berör personalens stödjande arbete till barnen, hur barns deltagande kan stärkas och hur barns sociala sammanhang kan bevaras i så stor utsträckning som möjligt, då vi sannolikt kommer att behöva leva med situationen under en lång tid. 


\section{Referenser}

Aitken, S. Lund, R. og Kjørholt, A.T. (red.). 2013. Global childhoods: Globalization, development and young people. London: Routledge.

Alvesson, M. och Sköldberg, K. 2018. Reflexive methodology: New vistas for qualitative research. 3:e uppl. Los Angeles, CA: Sage.

Amri, A., Haynes, K., Bird, D.K. och Ronan, K. 2017. Bridging the divide between studies on disaster risk reduction education and child-centred disaster risk reduction: a critical review. Children's Geographies, 16(3): 239251. DOI: 10.1080/14733285.2017.1358448

Anderson, W.A 2005. Bringing children into focus on the social science disaster research agenda. International Journal of Mass Emergencies and Disasters, 23 (3): 159-175

Bateman, A., Danby, S. och Howard, J. 2013. Living in a broken world: how young children's well-being is supported through playing out their earthquake experiences. International Journal of Play, 2:3:202-219. DOI: 10.1080/21594937.2013.860270.

Brooks, S.K., Webster, R.K., Smith, L.E., Woodland, L. Wessely, S, Greenberg, N. och Rubin, G.J. 2020 The psychological impact of quarantine and how to reduce it: rapid review of the evidence. The Lancet 395(10227): 912920. DOI: 10.1016/S0140-6736(20)30460-8

Cohen, L., Manion, L. och Morrison, K. 2018. Research Methods in Education. 8:e uppl. London/New York: Routledge.

Denzin, N.K. och Lincoln, Y.S. (red.) 2018. The SAGE handbook of qualitative research. 5:e uppl. Los Angeles: SAGE.

David, M. och Sutton, C. 2011. Samhällsvetenskaplig metod. Lund: Studentlitteratur.

Dolk, K. 2013. Bångstyriga barn: makt, normer och delaktighet i förskolan. Stockholm: Ordfront Förlag.

Freeman, C., Nairn, K. och Gollop, M. 2015. Disaster impact and recovery: what children and young people can tell us. Kōtuitui: New Zealand Journal of Social Sciences Online: Contested meanings of recovery: a critical exploration of the Canterbury earthquakes-voices from the social sciences. 10(2): 103-115, DOI: 10.1080/1177083X.2015.1066400
Furu, A-C. 2011. Resa i röstens landskap. En narrativ studie av hur lärare blir professionella röstanvändare. Diss. Åbo: Åbo Akademi.

Förenta Nationerna 1989. Konventionen om barnets rättigheter

Grunderna för planen för småbarnspedagogik 2018. Föreskrifter och anvisningar 2018:3b OPH-27912018. Helsingfors: Utbildningsstyrelsen.

Halldén, G. 2003. Barnperspektiv som ideologiskt eller metodologiskt begrepp. Pedagogisk Forskning i Sverige, 8(1-2): 12-23

Hatch, J. A. och Coleman-King, C. 2015. Conducting Early Childhood Qualitative Research in the Twenty-First Century. I: O.N. Saracho, red. Handbook of Research Methods in Early Childhood Education. Review of Research Methodologies, Vol 1. Charlotte, NC: Information Age Publishing, inc: 441-478

James, A. 2009. Agency. I: J. Qvortrup, W. Corsaro och M-S. Honig, red. The Palgrave Handbook of Childhood Studies. London: Palgrave Macmillan: 24-45

James, A., och James, A. 2008. Key concepts in childhood studies. London: Sage.

James, A. och Prout, A. 2015. A new paradigm for the sociology of childhood? Provenance, promise and problems. I: A. James och A. Prout, red. Constructing and reconstructing childhood. London: Routledge: 6-28

Jans, M. (2004). Children as citizens: Towards a contemporary notion of child participation. Childhood, 11(1): 27-44

Johansson, E. 2009. The preschool child of todayThe world-citizen of tomorrow? International Journal of Early Childhood, 41(2): 79-95

Last, M. 1994. Putting children first. Disasters (18):192-202

Läroplan för förskolan 2018. Lpfö 18. Stockholm: Skolverket.

Masten, A.S. och Barnes, A.J. 2018. Resilience in children: developmental perspectives. Children (Basel),5(7):98 DOI: 10.3390/children5070098 
Nijhof, S. L.et al. 2018. Healthy play, better coping: The importance of play for the development of children in health and disease. Neuroscience \& Biobehavioral Reviews, 95: 421-429.

Peek, L. 2008. Children and Disasters: Understanding Vulnerability, Developing Capacities, and Promoting Resilience. Children, Youth and Environments 18 (1): 1-29.

Pfefferbaum, B., Pfefferbaum R.L. och Van Horn, R.L. 2018. Involving children in disaster risk reduction: the importance of participation. European Journal of Psychotraumatology Children and natural disasters, 9(sup 2): 1425577-6. DOI: 10.1080/20008198.2018.1425577

Prilleltensky, I., Nelson, G. och Perison, L. 2001. The role of power and control in children's lives: An ecological analysis of pathways toward wellness, resilience and problems. Journal of Community \& Applied Social Psychology, 11, 143-158.

Sanson, A.V., Van Hoorn, J. och Burke, S.E.L. 2019. Responding to the impacts of the climate crisis on children and youth. Child Development Perspectives, 13 (4): 201-207.

SFS. 2020:148. Lag (2020:148) om tillfällig stängning av verksamheter på skolområdet vid extraordinära händelser i fredstid. Stockholm: Utbildningsdepartementet.

TENK. 2012. God vetenskaplig praxis och handläggning av misstankar om avvikelser från den i Finland. Forskningsetiska delegationens anvisningar 2012. Helsinki: Forskningsetiska delegationen
Ungar, M. 2011. The social ecology of resilience: Addressing contextual and cultural ambiguity of a nascent construct. The American Journal of Orthopsychiatry, 81(1): 1-17. DOI:10.1111 /j.1939-0025.2010.01067.

UNISDR. 2015. Sendai Framework for Disaster Risk Reduction 2015-2030. Geneve: United Nations - Headquarters, United Nations Office for Disaster Risk Reduction (UNISDR). https://www. undrr.org/publication/sendai-framework-disaster-risk-reduction-2015-2030

Vetenskapsrådet (2017). God forskningssed. Reviderad utgåva. Stockholm: Vetenskapsrådet. Tillgänglig på Internet: https://www.vr.se/ analys/vara-rapporter/2017-08-29-god-forskningssed.html

Wang, G., Zhang, Y., Zhao, J., Zhang, J. och Jiang, F. 2020. Mitigate the effects of home confinement on children during the COVID-19 outbreak. The Lancet, 395(10228): 945-947 https://doi.org/10.1016/S0140-6736(20)30547-X

Weale, S. 2020. Fifth of primary children afraid to leave house over Covid-19, survey finds. The Guardian, International edition. 2020-04-10, Guardian News \& Media Limited. Nedladdat den 2020-05-27 https://www.theguardian. com/world/2020/apr/10/fifth-of-primarychildren-afraid-to-leave-house-because-ofcovid-19-survey-finds

WHO 2020. Coronavirus disease (COVID-19) pandemic. https://www.who.int/emergencies/ diseases/novel-coronavirus-2019

Wood, E. A. 2014. Free choice and free play in early childhood education: troubling the discourse. International Journal of Early Years Education, 22 (1): 4-18, DOI: 10.1080/09669760.2013.830562 


\section{Författarpresentationer}

Mia Heikkilä är biträdande professor i småbarnspedagogik vid Åbo Akademi, Fakulteten för pedagogik och välfärdsstudier. Hennes forsknings är riktad mot frågor som handlar om övergripande samhällsfrågor om organisation och förändring kring pedagogisk verksamhet för yngre barn, och mer specifikt om barns lek och lärande med särskild inriktning mot social rättvisa och genus.

E-post: mia.heikkila@abo.fi

Ann-Christin Furu är doktor i pedagogik och lektor i småbarnspedagogik vid Helsingfors universitet, Pedagogiska fakulteten och Åbo Akademi, Fakulteten för Pedagogik och välfärdsstudier. Hennes forskning är inriktad på hållbarhetspedagogiska frågeställningar och lärares professionalism. Ett särskilt fokus är kommunikationens och relationens betydelse för barns utveckling och lärande.

E-post: christin.furu@abo.fi
Anette Hellman är docent i pedagogik vid Göteborgs universitet, Institutionen för pedagogik, kommunikation och lärande och vetenskaplig ledare för forskningsmiljön Global Childhoods. Hennes forskningsintressen handlar barn och ungas vardagsliv ur ett internationellt perspektiv. Anette har varit redaktör för publikationer såsom Learning Spaces for Inclusion and Social Justice in Nordic Early Childhood Education.

E-post: anette.hellman@ped.gu.se

Anne Lillvist är doktor i psykologi och docent i pedagogik vid Örebro Universitet, Institutionen för Humaniora, Utbildning och Samhällsvetenskap, Enheten för pedagogik. Hennes forskningsintresse fokuseras på specialpedagogiska frågor i förskolan, kvalitetsaspekter i förskola samt övergångar mellan olika skolformer. E-post: anne.lillvist@oru.se

Anna Rantala är doktor i pedagogiskt arbete och lektor i utbildningsledarskap vid Umeå Universitet, Centrum för skolledarutveckling. Hennes forskningsintresse handlar om fostran i förskolan men ett särskilt fokus på normer och värderingar. E-post: anna.rantala@umu.se 